\begin{tabular}{|c|c|c|}
\hline+1 & $\begin{array}{c}\text { European Association for the } \\
\text { Development of Renewable Energies, Environment } \\
\text { and Power Quality (EA4EPQ) }\end{array}$ & $\begin{array}{l}\text { Int ernational Conference on Renewable Energies and Power Quality } \\
\text { (ICREPQ'12) } \\
\text { Santiago de Compostela (Spain), 28th to 30th March, } 2012\end{array}$ \\
\hline
\end{tabular}

\title{
Efficiency analyze Borehole Heat Exchangers (BHEs) of the research geothermal polygon placed at VŠB-Technical University of Ostrava
}

\author{
P. Bujok ${ }^{1}$, V.K. Chistyakov ${ }^{2}$, M. Klempa ${ }^{1}$ and I.A. Straupnik ${ }^{2}$ \\ ${ }^{1}$ VŠB - Technical University of Ostrava \\ 17.listopadu 15/2172, Ostrava-Poruba, 70833 (Czech Republic) \\ Phone number: +420 597325 278, Fax nu mber: +420 596918 507e-mail: petr.bujok @ vs b.cz, martin.klempa@ vs b.cz \\ ${ }^{2}$ Saint - Petersburg State Mining University \\ 21 line of Vasiljevsky Island, 2, Saint-Petersburg, 199106 (Russian Federation) \\ Phone number: +7 81232882 00, Fax nu mber: +7 8123288698 e-mail: tch-vk @ mail.ru, straupnik @ rambler.ru
}

\begin{abstract}
Among renewable energies, low-temperature geothermal energy is gaining importance due the different applications that are being accomplished within residential sector. Forecasts suggest a "promising future" for this energy source.

A study carried out during the realization and operation of the Research Polygons placed at VSB - Technical University of Ostrava. New University Hall is heated up by the heat pumps. This object is the biggest building in the Czech Republic and in the Central Europe which uses this type of the system. Monitoring boreholes are situated in the area of heat pumps boreholes. They are equipped with heat sensors which monitoring temperature changes in circulations systems and in the rock massive during heating (accumulation of heat that comes from air conditioning in summer) and during cooling (pumping of heat from the rock massive by heat pumps in winter). The main goal is to efficiency analyze Borehole Heat Exchangers (BHEs) of the Research geothermal Poly gons.
\end{abstract}

Key words: Research polygon, renewable energy, temperature measurement, heat pump, energy efficiency.

\section{Introduction}

Project Start: "Investigation of heat changes in rock mass (cooling-heating) under application of heat pumps in the locality of New University Hall + CIT of the VSB-TU of Ostrava" was enabled by means of a purpose investment grant donated from Moravian-Silesian County's budget in 2007 - 2009. In 2010 the investigation continued further within a CEZ's Project - Green Energy. At the moment it is solved as a project of the Technical Agency of CR, TACR-ALFA ev. no. TA01020932.

The aim of the project solution consists in evaluation of the importance of internal and external sources influence on heating balance of the rocks in monitored low energetic system from the point of renew ability of this alternative source (heat subsidies for example from air-conditioning) and designation of a regularity of changes of earth's thermal flow in non homogeneous rock mass of the monitored locality (Miocene, Carboniferous) in surroundings of the energetically utilized boreholes.

For evaluation of aliquot parts of the individual internal and external sources of energy from the total thermal balance, for attestation of systems designed for long term monitoring of the rock mass behaviour in the surroundings of energetically utilized boreholes and of possibilities of energy accumulation, two research measuring polygons were designed and subsequently realised. It means a Large Research Polygon (LRP) and a Small Research Polygon (SRP) [1].

The Large Research Polygon (designated especially for monitoring of influence of massive heat off-takes from the rock environment) is situated nearby the new University Hall + CIT.

Total built up area is $3,197 \mathrm{~m}^{2}$; total floor area is $9,234 \mathrm{~m}^{2}$. The installed system of heat pumps is created by ten Swedish heat pumps from IVT company of Greenline D70 type with total power output of $700 \mathrm{~kW}$ and by a network of 110 boreholes $140 \mathrm{~m}$ deep (the total length of boreholes is $15,400 \mathrm{~m}$ ) that were built up at the area of the new University Hall of VSB - TUoO parking place and at a parking place next to the new library of VSB - TU of Ostrava (fig.1).

The S mall Research Polyg on (designated es pecially for research of thermal, regenerative and accumulative behaviour of the rocks in surroundings of energetically utilized boreholes nearby small objects) is situated nearby the Research Energetic Centre of the VSB-TUoO. Both the polygons mentioned above are situated in the Campus of VSB-TUoO in Ostrava-Poruba. 


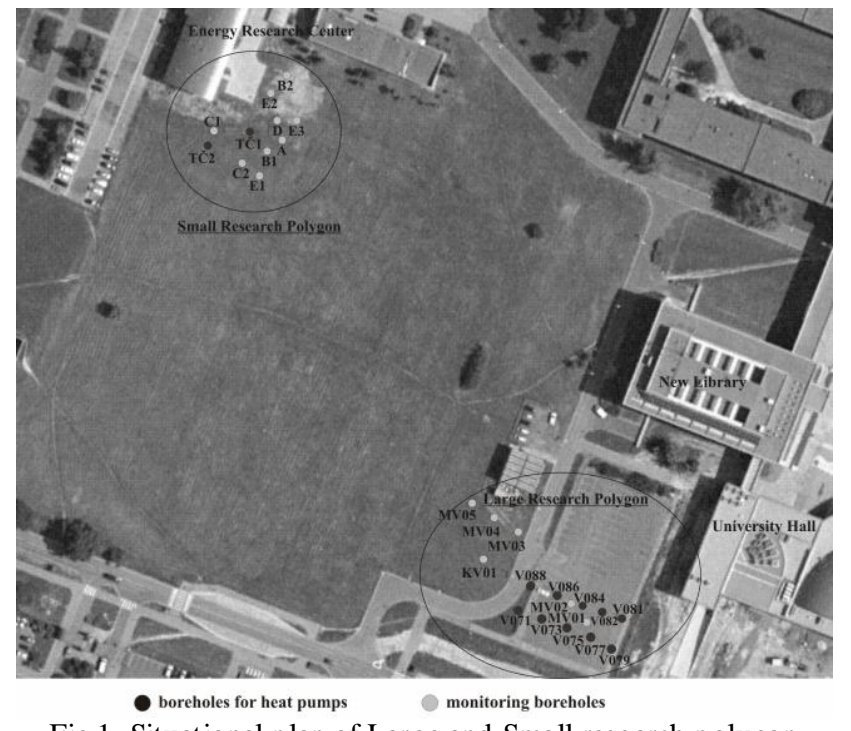

Fig.1. Situational plan of Large and Small research poly gon

There was analyzed a huge array of data for the period since September 2007 to May 2010.

\section{The geothermal boreholes system}

In this paper attention is paid to geothermal boreholes. The system consists of the boreholes, measuring system, system of heat exchange collector.

\section{A. Boreholes}

Operational boreholes were equipped by pairs of PE collectors, $32 \mathrm{~mm}$ in diameter. Between input (cool) side of the collectors a system of temperature sensors of PT-1000 type was mounted. That is in depths of 20, 50, 100 and 140 $\mathrm{m}$. The same temperature sensors were mounted between output (warm) side of the collectors in depths of 20 and 100 m.. Monitoring boreholes were equipped by bearing $\mathrm{PE}$ tubes, $32 \mathrm{~mm}$ in diameter (exceptionally $40 \mathrm{~mm}$ diameter of MV03 borehole). System of four temperature sensors of PT-1000 type was mounted between these tubes. That is in depths of 20,50,100 and $140 \mathrm{~m}$. Some geological and technical parameters of the boreholes are presented on the Table I, and the scheme of temperature sensors is presented on Fig.2.

Table I. - Geotechnical parameters

\begin{tabular}{|c|c|c|c|c|c|}
\hline \multicolumn{2}{|c|}{ Depth, m } & \multirow{2}{*}{$\begin{array}{l}\Xi \\
\dot{\Xi} \\
Q\end{array}$} & \multirow{2}{*}{$\begin{array}{l}\text { Description of } \\
\text { the soils }\end{array}$} & \multirow{2}{*}{$\begin{array}{l}\text { Type of } \\
\text { collector }\end{array}$} & \multirow{2}{*}{$\begin{array}{l}\text { Type } \\
\text { of } \\
\text { filler }\end{array}$} \\
\hline from & to & & & & \\
\hline 0 & $\infty$ & in & Loam & \multirow{4}{*}{ 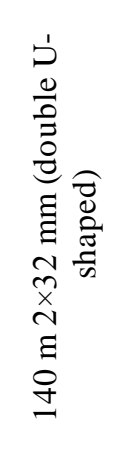 } & \multirow{4}{*}{ 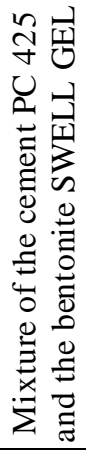 } \\
\hline$\infty$ & N & n & $\begin{array}{l}\text { Interbedded } \\
\text { s ands }\end{array}$ & & \\
\hline ป & ஓ & $\stackrel{ }{\sim}$ & Dense clay & & \\
\hline ஓ & $\stackrel{\circ}{ \pm}$ & $\stackrel{ }{\text { ㄱ }}$ & $\begin{array}{l}\text { Interbedded } \\
\text { sandstones and } \\
\text { mudstones }\end{array}$ & & \\
\hline
\end{tabular}
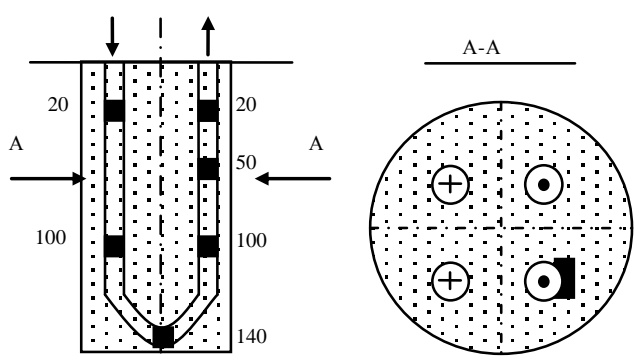

Fig.2. Scheme of temperature sensors.

\section{B. Measuring system}

Measuring system consists of: system of sensors in boreholes, programmable automatic machine enabling automatic measuring of temperatures, cumulative channel, monitoring system. Data come from resistive temperature sensors of PT 1000 placed in individual boreholes. It deals especially with the sensors that dispos of an output in configuration of variable resistance size. X20AT4222 modules process data from these sensors. However, the second part of used resistive temperature PT 1000 sensors disposes of digital output on RS232 bus. Dig ital outputs from these sensors are processed directly by X20CP1484 processor unit of X20 system. A part of the control system is also a PC communicating with the main PLC by means of the communicating bus of Ethernet. Programming Support Environment of B\&R Automation Studio has been installed on this PC. It serves for development and programming of the control application itself. Visualization environment of Promotic has been also installed on this PC. Complete visualization of the whole control system is executed here. By it, a user can monitor individual temperatures of every sensor and execute appropriate operations with measured data (archiving, deleting, adding or similar).

Processing is possible thanks to special software developed by Swedish company - ELCOM AUTOMATION, which produce heat pumps and which was engaged in construction and equipping of the Polygon. The scheme of the research polygon and software allows providing information from the Polygon in real time mode (Fig. 3).

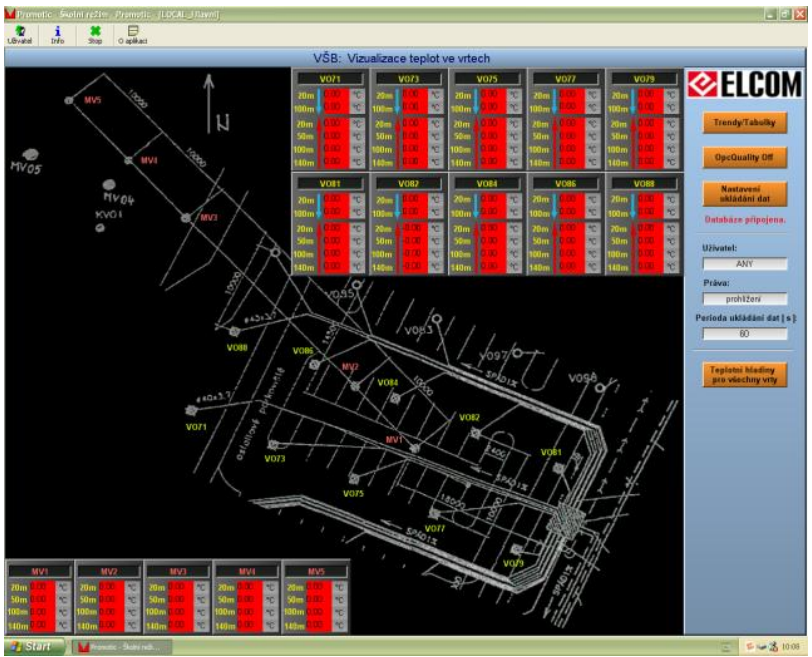

Fig.3. Scheme of the research poly gon and data visualization of temperatures in boreholes. 


\section{System of heat exchange collector}

Borehole collectors consist of double U-shaped pipes PE $2 \times 32 \mathrm{~mm}$ and lead-in pipes on the surface. The operating boreholes are connected and the heat career circulates from the common storing well.

\section{Data analy ze}

The first phase of work included the processing of information received from the measuring system, namely statistical analysis, the exclusion of erroneous data; identify malfunctioning sensors and presentation of information in the graphs form.

After the information processing it have been allocated the most interesting periods of the system operating, namely, the most loaded and informative one's were presented in graphical form (Fig.4).

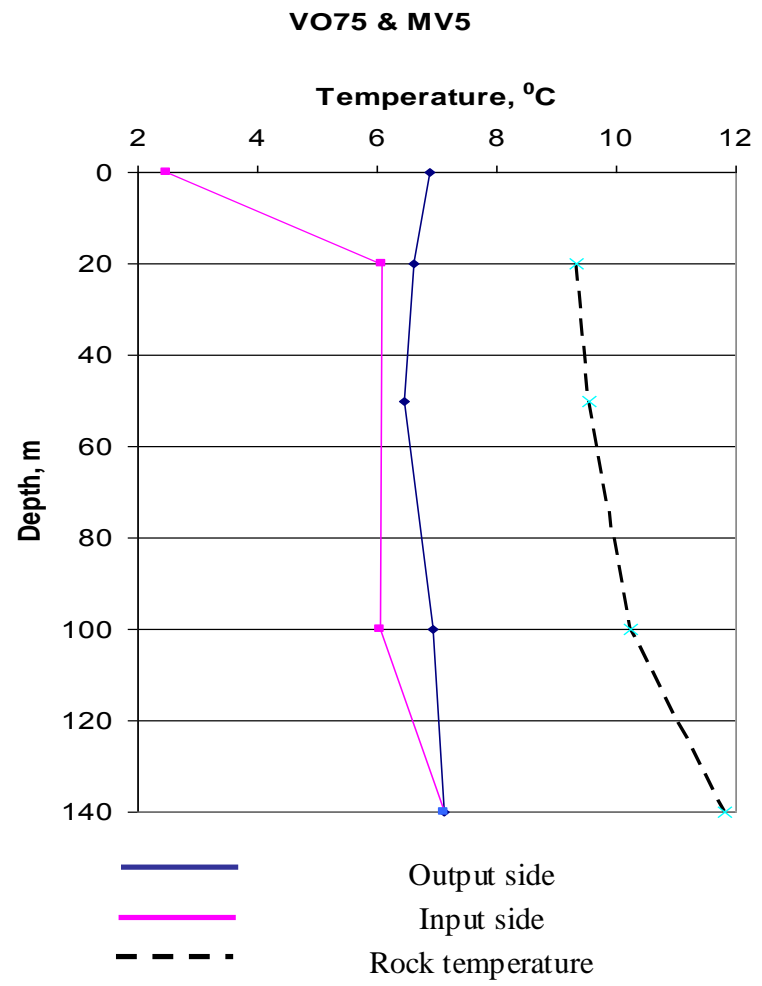

Fig.4. Appearance of processed data.

Data from some sensors were not received and these values were zero or had false values (fig.5). Some sensors have worked with systematic errors.

The second phase included the identification of the active period of the borehole system equipped with temperature sensors and the identification patterns between cycles of the system and temperature fluctuations in the boreholes.

The periodicity of the heat pump was calculated; also it was calculated the time of its functioning for these periods. These periods were compared to data obtained by means of borehole temperature measurement system (fig.6).

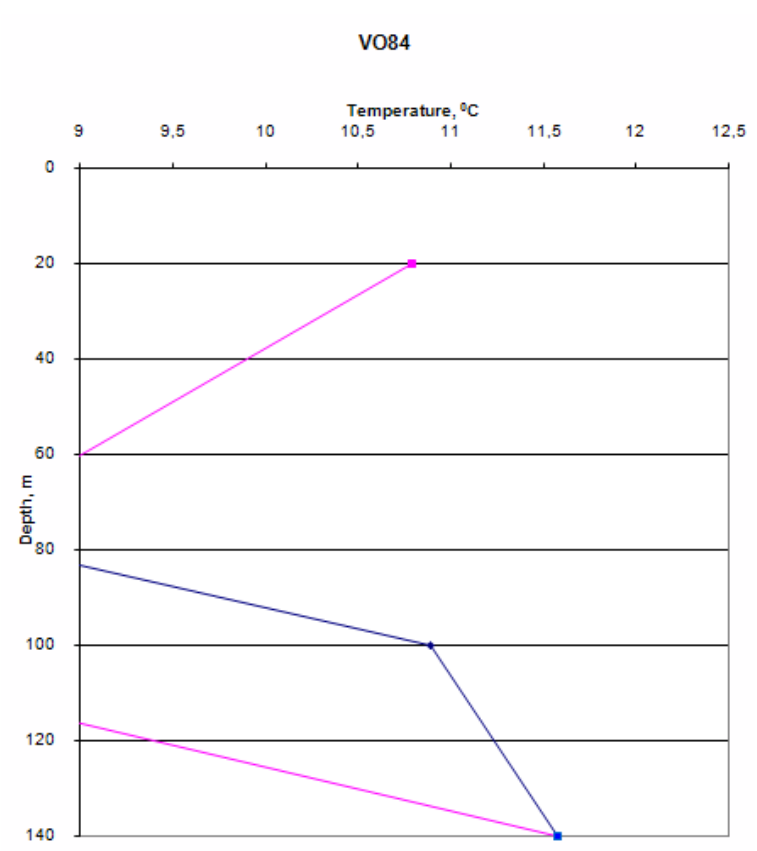

Fig.5. The example of graph with error data.

V071 140

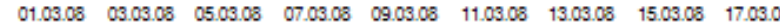
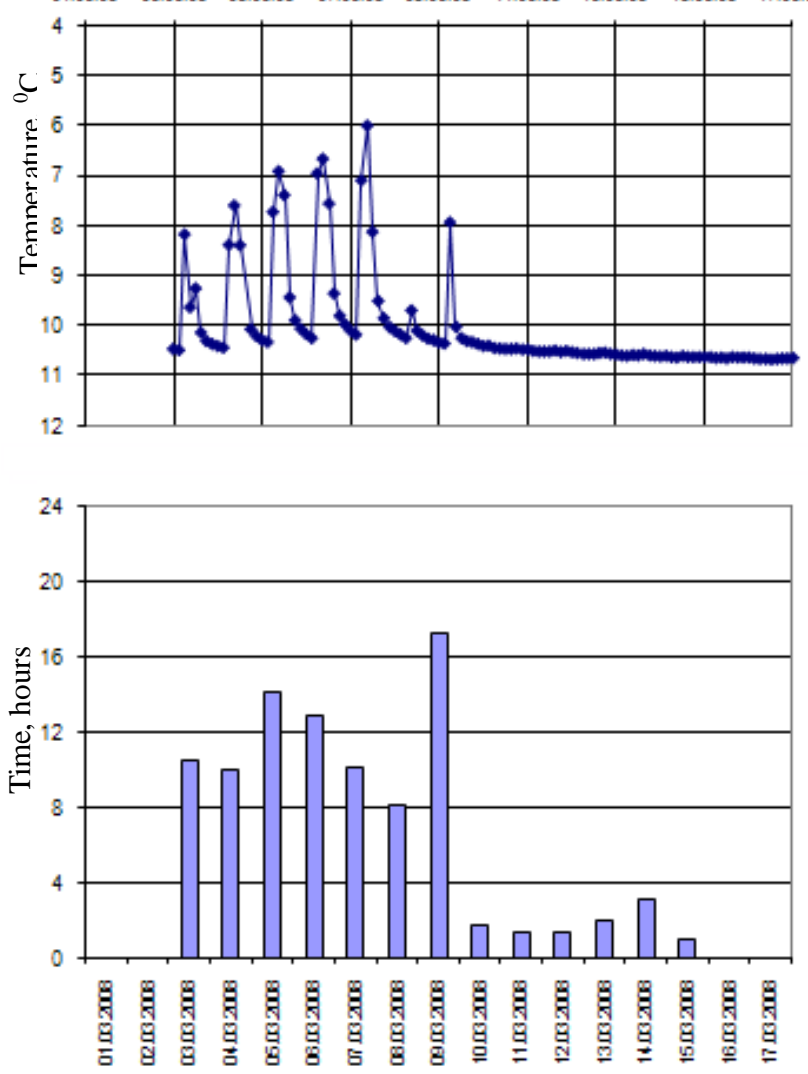

Fig.6. Data combining. The upper graph - temperature received from sensor $140 \mathrm{~m}$ VO71 borehole. The lower graph - the time of heat pump functioning for same period.

The third stage included the determination of the system operation influence on the surrounding rock mass, using information from the five monitoring boreholes.

The last stage of the analysis was to determine the efficiency of the borehole heat exchanger loop. 


\section{Conclusions}

It is important to notice the imperfection of measuring system reasoned by the fact that the temperature is not measured directly in the flow of coolant but the surface of collector PE pipe. In this regard, one of the problems requiring solution is the creation of a new measuring system in the new boreholes that will be done in the nearest future. It is planned to equip the boreholes with the special OPTO-cable, which will measure the temperature not discrete depth value, but the entire depth. The quality of the received data has been lowed permanently (fig.7)

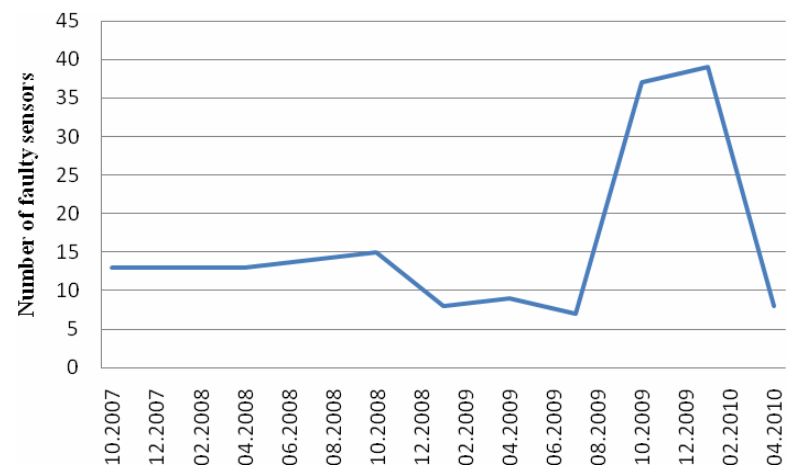

Fig.7. Dynamics of the faulty sensors number.

The depth of boreholes unfounded, because according to received data, it is obvious that the heat transfer occurs in the pre-surface zone. According to analyze it appears that the main heat exchange happening down to the approximately depth $50 \ldots 70 \mathrm{~m}$. Variation of the temperature in five monitoring boreholes do not exceed $0,1^{\circ} \mathrm{C}$, this fact also confirmed by the data for other time periods. Based on this data it can be concluded that the zone of boreholes influence was less than $5 \mathrm{~m}$ in this variant of heat pump operation operating, this distance is a distance between the borehole MV1 and VO75 и VO84 (Fig.1 and 3). But this conclusion can be not correct because of borehole inclination, according to [2] vertical inclination can be from $1,82 \mathrm{~m}$ to $2,78 \mathrm{~m}$.

Also, the data of heat pump functioning was processed, and this data were obtained on the values of the input and output temperature of the heat exchange borehole collector. It is become known temperature gradient, which is the main aim of borehole circulation system functioning. This temperature difference ranged from 3.5 to $5^{\circ} \mathrm{C}$.

It should be noted the effectiveness of the system in terms of fulfilling its immediate task, such as, heating and air conditioning. However, it also should be noted that the mode of the borehole system operation is irrational, as it is not noted any temperature influence on the surrounding rock mass. It is possible to increase the duration of the borehole functioning. It turns out that the number of functioning boreholes is too high. It can be used the efficiency estimation criteria (1) for the BHEs [3]:

$$
\eta=\frac{N_{1}-N_{2}}{N_{1}}=1-\frac{\Delta P(Q ; H)}{c \rho \cdot \Delta t(Q ; H)}
$$

$N_{1}$ - given power, $N_{2}$ - spent power, W; $\Delta P$ - hydraulic pressure losses, $\mathrm{Pa}$; $c$ - heat career (HC) heating capacity, $\mathrm{J} /(\mathrm{kg} \cdot \mathrm{K}) ; \rho-\mathrm{HC}$ density, $\mathrm{kg} / \mathrm{m}^{3} ; \Delta t$ - temperature difference between input and output line on the surface in chink of borehole, $\mathrm{K} ; Q-\mathrm{HC}$ expanse, $\mathrm{m}^{3} / \mathrm{sec} ; H$ - borehole depth, $\mathrm{m}$.

As the measuring system and there is no information about $\Delta t(1)$, it is possible to estimate the efficiency with the data from the $20 \mathrm{~m}$ depth. This depth is lower than layers which are in the season temperature fluctuation zone (fig.8).
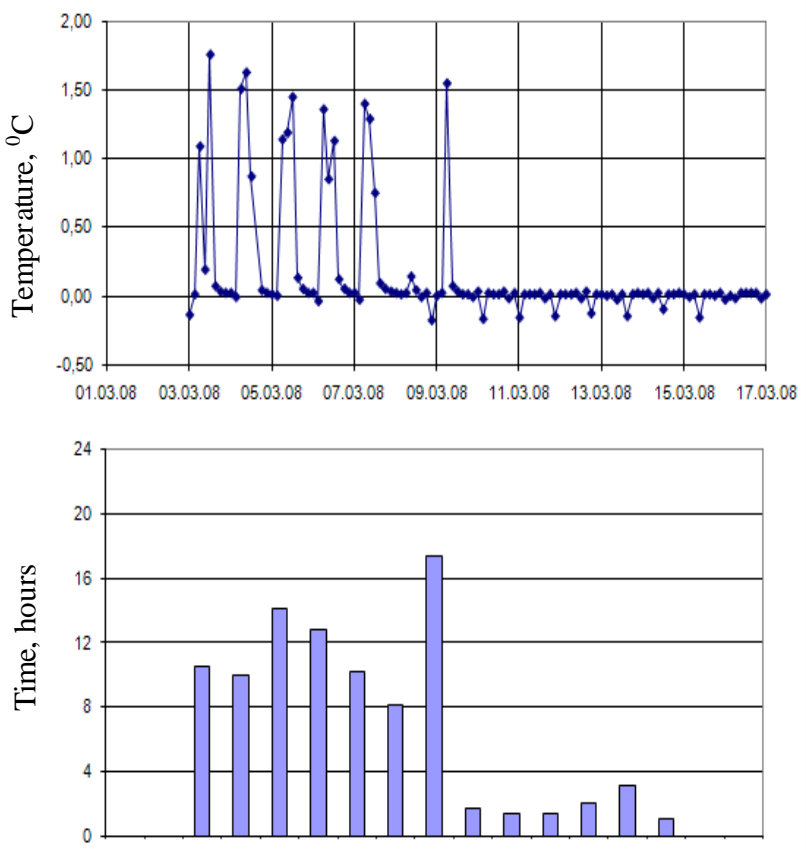

Fig.8. Data combining. Difference of temperature on the $20 \mathrm{~m}$ depth in VO71 and the time of heat pumps functioning.

According to the graph above the efficiency of the BHEs has strong relation with the circulation mode.

\section{Acknowledge ment}

A part of works was realised under support of a grant project TACR - ALFA ev. no. TA01020932 "Utilization of Earth Crust Heat Energy for Formation of Renewable Energy Sources including Possibilities of Heat Accumulation".

\section{References}

[1] M. Klempa, P. Bujok, P. Pospisil;R. Hajovsky, "The experiences from construction and operations of the experimental underground heat storage reservoir in the campus of VSB - Technical university of Ostrava, in Proc. 11th International Multidisciplinary Scientific GeoConference, 20 25 June 2011, pp 115-122, Albena, Bulgaria, ISSN 1314-2704.

[2] P. Bujok,, M. Klempa,, R. Rado, Analiza pomiarów inklinometrii $\mathrm{w}$ otworach geotermalnych na poligonie doświadczalnych VŠB-Uniwersytet Techniczny w Ostrawie. Wiertnictwo Nafta Gas, TOM 27, Zeszyt 1-2, ss. 91-100, ISSN 1507-0042, 2010.

[3] И.А. Страупник, В.К. Чистяков, «Расчет и оценка эффективности теплообменных скважин». Проблемы научно-технического прогресса в бурении скважин, сборник докладов, 23-25 ноября 2009, Изд-во ТПУ, С. 84 89, г. Томск, Россия 